\section{B A Institute of \\ YK Business Administration \\ 六下 \\ Karachi \\ Leadership and Ideas for Tomorrow}

Business Review

Volume 8 Issue 2 July-December 2013

$7-1-2013$

\title{
Study of economic development of Pakistan through stock market: Causal relationship of stock prices and macroeconomic indicators
}

\author{
Rizwan Raheem Ahmed \\ Institute of Business Administration, Karachi, Pakistan \\ Yaseen Ahmed Meenai \\ Institute of Business Administration, Karachi, Pakistan \\ Fazal Hussain \\ Institute of Business Administration, Karachi, Pakistan
}

Follow this and additional works at: https://ir.iba.edu.pk/businessreview

Part of the Growth and Development Commons, and the Macroeconomics Commons

\section{(c) (1)}

This work is licensed under a Creative Commons Attribution 4.0 International License.

\section{Recommended Citation}

Ahmed, R. R., Meenai, Y., \& Hussain, F. (2013). Study of economic development of Pakistan through stock market: Causal relationship of stock prices and macroeconomic indicators. Business Review, 8(2), 124-141. Retrieved from https://doi.org/10.54784/1990-6587.1291

This article is brought to you by iRepository for open access under the Creative Commons Attribution 4.0 License and is available at https://ir.iba.edu.pk/businessreview/vol8/iss2/10. For more information, please contact irepository@iba.edu.pk. 
https://ir.iba.edu.pk/businessreview/vol8/iss2/10

DOI: https://doi.org/10.54784/1990-6587.1291

Business Review - Volume 8 Number 2

July - December 2013

CASE STUDY

\title{
Study of Economic Development of Pakistan through Stock Market: Causal Relationship of Stock Prices and Macroeconomic Indicators
}

\author{
Rizwan Raheem Ahmed \\ Yaseen Ahmed Meenai \\ Fazal Hussain \\ Institute of Business Administration, Karachi, Pakistan
}

\begin{abstract}
The purpose of the research is to examine the causal relationship between stock prices and the variables representing the real sector of the economy for example real GDP, and real investment, in Pakistan. In this study, annual data is used (quarter-wise) from December 1980 to June 2007 and the correlation analysis has been applied, to investigate the relationship. For better understanding of the Market's Behavior, data has been grouped in to Liberalization periods; Preliberalization and Post-Liberalization.

The stock market in Pakistan provides an average quarterly return of 2.86\%.The average annual growths in real variables are just lower than $1 \%$ for GDP and returns slightly over $1 \%$ in investments. A comparison of the descriptive statistics between the two sub-periods indicates decline in the average growth in real variables. Real GDP fell , and real investment also decreased. The decline is significant both in GDP and investment. Though the magnitude of the average growth in stock price index increased in the second period it is not significantly different from that of the first period.
\end{abstract}

The descriptive statistics indicates a much higher expansion in stock prices relative to real variables. However, the stock prices also experienced higher volatility during the sample period whereas the real variables seem to be stable.

Key Words: Causal Relationship, Stock Price index, Real Sector of the Economy, GDP \& Real Investment, Higher Volatility, Pre-Liberalization, and Post-Liberalization

\section{Introduction}

\subsection{Background of the Study}

The stock market plays an important role in the economy by mobilizing domestic resources and channeling them to productive investment. This implies that it must have a significant relationship with the economy. The relationship can be seen in two ways - The first relationship views the stock market as the leading indicator of the economic activity in the country whereas the second focuses on the possible impact the stock market may have on aggregate demand particularly through aggregate consumption and investment. In other words, whether changes in stock market cause fluctuations in macroeconomic variables, like Consumption Expenditures, Investment Spending, Gross Domestic Product (GDP), Index of Industrial Production (IIP), etc., or are caused by these variable is an interesting issue to be examined. The 
former case implies that stock market leads economic activity whereas the latter suggests that it lags economic activity.

The knowledge of the relationship between stock prices and macro variables is now becoming more important in the case of developing countries in view of the various economic reforms taking place there, starting, in the beginning of the 1990s there have been a number of measures taken for economic liberalization, privatization, relaxation of foreign exchange controls, and in particular the opening of the stock markets to international investors. These measures resulted in significant improvements in the size and depth of stock markets in developing nations and they are beginning to play their due role. (Husain \& Mahmood, 2001)

The issue that highlights whether stock market leads or lags economic activity is now becoming very crucial in Pakistan, as the stock market has gained much attention in the last few years. The stock market has been, in general, among the best performing markets. The indicators like market capitalization, trading volume, the market index have shown phenomenal growth. These developments are often claimed by the authorities to be an indication of economic progress of the country. It would be useful to examine whether these developments have influenced the economy, particularly the real sector. Moreover, the relationship between stock prices and the real sector variables is also important in view of the various economic reforms initiated in early 1990s. The measures taken for economic liberalization, privatization, relaxation of foreign exchange controls, and in particular the opening of the stock markets to international investors were supposed to greatly impact the economy including the real sector. (Fazal Husain, 2006)

\subsection{Role of the Securities Market in Economic Development}

The deepening and level of sophistication of modern financial markets is arguably a recent phenomenon. However, stock markets have long played a significant role in economic life.

Most academicians and policy makers in developing countries hold the view that securities market development is a key element of financial deepening as this market provides a variety of financial assets to the economy to facilitate resource mobilization for investments. Arguments against the benefits of securities market development are hardly heard. Securities market development is often regarded as an important barometer of financial deepening in developing countries where financial sectors are represented mainly by the banking industry. The importance of securities market development to financial development is sometimes emphasized to the extent that it is regarded as a necessary condition for complete financial liberalization. Despite the general perception that securities market development is an evolutionary process, correlated with the level of income per capita, the question that has not yet been answered satisfactorily, is, why one country with a lower income per capita may have a much more advanced securities market than a higher income country?

Agtmael and Errunza (1982) summarize and provided a wide range of arguments for the positive role of the securities market in economic development. The securities market could:

1. Raise funds for investments through issuance of new securities.

2. Improve efficiency and solvency of the financial system by increased competition in the system and improved financial structure.

3. Facilitate mobilization of financial savings by providing an incentive to save, invest and compete with other financial assets. 
4. Improve allocated efficiency of investment by reducing the distortion of planned allocation of resources, which is often plagued with political favoritism, special privileges of the public sector over the private initiative, preference for large projects over small businesses, credit rationing and distorted interest rates.

5. Enhance solvency of the corporate sector by strengthening the financial structure of corporations.

6. Asset decentralization of ownership by promoting the spread of ownership participation by the general public.

7. $\quad$ Expand access for new and emerging companies to venture capital.

8. Improve accounting and auditing procedures and standards through disclosure of regular, adequate and reliable information, checked by independent auditors.

\subsection{Stock Markets and Economic growth}

For more than a decade stock markets have boomed in about every country. From 1984 to 1994 the capitalization of world stock exchanges grew fivefold to a combined \$18 trillion. Most of this money is still invested in industrial nations, but the dramatic growth has been in the emerging countries. Foreign investors increased their annual net investments in emerging markets from \$13 billion in 1990 to \$61 billion in 1993.

\subsection{Purpose of the Study}

The purpose of the research is to examine the causal relationship between stock prices and the variables representing the real sector of the economy like real GDP and investment spending in Pakistan. The recent phenomenon is what is being studied and the issues regarding the efficiency, seasonality, volatility and other characteristics of the stock market as well as the role of the stock market in the economic development of Pakistan is scrutinized. In this study, all the aforementioned key issues will be discussed in a quantitative perspective and the results of the study determine the role of the stock market in the economic development of Pakistan, markets' behavior and other characteristics of the market.

\section{Review of Literature}

\subsection{Stock Market Development and Long-run growth}

The theoretical basis to examine the link between stock prices and the real variables are well established in literature, e.g., in Baumol (1965), Bosworth (1975). The relationship between stock prices and real consumption expenditures, per say cycle theory, developed by Ando and Modigliani (1963), states that individuals base their consumption decision on their expected lifetime wealth. Part of their wealth may be held in the form of stocks eventually linking stock price changes to changes in consumption expenditure. Similarly, the relationship between stock prices and real investment spending is based on the q theory of James Tabin (1969), where $q$ is the ratio of total market value of firms to the replacement cost of their existing capital stock at current prices. Finally, the relationship between stock prices and GDP, a measure of economic activity, indicates whether the stock market leads or lags economic activity.

Hussain and Mahmood (2001), covering the data from 1959/60 to 1998/99 report an unidirectional causality from the macro economic variables, GDP, consumption, investments, to stock prices, implying that the stock market lags economic activity and thus cannot be characterized as the leading indicator of the economy in Pakistan.Devereux and Smith (1994) 
emphasize that greater risk sharing through internationally integrated stock markets can actually reduce saving rates and slow economic growth. Finally, Shleifer and Summer's (1988) and Morck, Shleifer, and Vishny's (1990), analyze that stock market development can hurt economic growth by easing counterproductive corporate takeovers. Moreover, Joan Robinson (1952) argues that the financial system does not spur economic growth; financial development simply responds to developments in the real sector. Thus, many influential economists give a very minor, if any, role to the financial system in economic growth.

In contrast, a prominent line of research stresses the role of the financial system in economic growth. Bagehot (1873), Schumpeter (1912), and Cameron, et. al. (1967), Goldsmith (1969), and McKinnon (1973) all provide conceptual descriptions of how and empirical examples of when the financial system affects economic growth. Building on these seminal contributions, Gelb (1989), Ghani (1992), King and Levine (1993), and De Gregorio and Giudotti (1995) show that measures of banking development are strongly correlated with economic growth in a broad cross-section of countries.

\subsection{Risk Diversification - International Integration}

Theory suggests that the ability to diversify risk by investing in an internationally diversified portfolio of stocks can influence investment decisions and long-run growth rates [Devereux and Smith (1994) and Obstfeld (1994)]. However barriers to international capital flows such as taxes, regulatory restrictions, information asymmetries, sovereign risk, etc. may impede the ability of investors to diversify risk internationally. Thus, international capital flow barriers will impede risk diversification, reduce capital market integration, and keep arbitragers from equalizing the price of risk internationally. To measure the ability of agents to diversify risk internationally, we use Korajczyk's (1996) estimate of the degree of international integration of national stock markets.

The results suggest a strong positive relationship between stock market development and long-run economic growth. The instrumental variable results show that the predetermined component of stock market development as extracted by the first-stage regressions is strongly and positively correlated with economic growth. Moreover, the results hold after checking for outliers and reproving individual countries. As discussed in the introduction, measurement, statistical and conceptual problems impedes cross-country growth regressions. Nonetheless, the results suggest a comparatively strong link between the functioning of stock markets and economic growth.

\subsection{Financial Factors in Economic Growth; The Theoretical Nexus}

Why it is that financial development spurs economic growth? In a frictionless ArrowDebreu World there is no room for financial intermediation. Explaining the role played by stock markets or banks requires building in frictions such as informational or transaction costs into the theory. Different frictions motivate different types of financial contracts, markets and institutions. The functional approach of Levine (1991) provides a useful framework to think about the role of financial intermediaries. They perform five interrelated functions. Each of these financial functions can increase growth through two channels: capital accumulation and technological innovation. We briefly review the functions and illustrate them for the case of Belgium in the remainder of the paper. First, financial intermediaries facilitate pooling and trading of risk. Without financial markets, investors facing liquidity shocks are forced to withdraw funds invested in long-term investment projects. 


\subsection{Cross-Country Econometric Evidence}

There is substantial cross-country evidence that country with a better-developed stock market and banking system witness higher subsequent growth. Most studies focus on the postwar era. The idea that finance matters for growth in the early stages of economic development goes back to Patrick (1966), Cameron (1967) and Goldsmith (1969). In his study, Goldsmith (1969) establishes the important stylized fact that periods of above average rates of economic growth tend to be accompanied by faster, financial development. King and Levine (1993) document a robust relationship between initial levels of financial development and subsequent economic growth across 80 countries, after controlling other growth-inducing factors. Their measures of financial development are based on the degree of monetization and bank development. Rousseau and Sylla (2001) also employ a cross-country regression framework to make the case for finance-led growth. They use a long data set (1850-1997) for the US, the UK, Japan, France, Germany, and the Netherlands. In their findings, they consistently argue that financial factors had the strongest effect in the 80 years prior to the Great depression.

Levine and Zervos (1996) conduct a similar analysis for 48 countries and for the period 1976-1993, but focus on the role played by the stock market. They measure stock market development along various dimensions: size, liquidity, international integration and volatility. More precisely their measures are aggregate stock market capitalization to GDP and the number of listed firms (size), domestic turnover and value traded (liquidity), integration with world capital markets, and the standard deviation of monthly stock returns (volatility).

\subsection{Time-Series Econometrics Evidence}

Hansson and Jonung (1997) investigate the case of Sweden from 1830 to 1991. In a bivariate system, they find that bank development is cointegrated with per capita GDP for the entire period 1834-1991, but the relationship is unstable over time. Banking has the strongest influence on the real economy in the interval 1890-1939 and to a lesser extent in the period 18341890. Rousseau and Wachtel (1998) compare the US, the UK, Canada, Norway and Sweden for the period 1870-1929. This comparative 5-country study uses the same methodology to study trivariate systems of GDP, the monetary base and financial intensity, measured by the value of the financial sector's assets. The authors find a single co-integration relationship between the three variables under examination, suggesting persistent co-movements between finance and growth.

Demetriades and Hussein (1996) and Van Nieuwerburgh (1998) apply co-integration analysis to a mixed sample of developing and developed countries for the postwar era. Financial development variables, which are bank-based, are co integrated with economic development. In both studies, the direction of causality varies across countries and depends on the measure of financial development used.

\section{Research Methodology}

\subsection{Data and Methodology}

The study was based on annual data from December 1980 to June, 2007, to investigate the causal relations of stock prices with the variables of the real sector in Pakistan, specifically the real GDP and the real investment spending. The sample is further classified into two sub-samples to take care of the economic liberalization program started in the early 1990s. Hence, Sample-I, from December 1980 to March 1991, covers the period prior to the start of the liberalization program 
whereas, Sample-II, from April 1991 to June 2007 represents the post-liberalization period. Similarly in regression analysis the study includes a dummy variable from April 1999 to June 2007 to take care of the possible shift in relations between variables due to economic liberalization program.

\subsection{Data Sources}

State Bank General Price Index (SBGPI) represented stock prices with base 1980-81. Similarly, investment spending and GDP at constant prices of 1980-81 are used as variables representing the real sector of the economy. The principal data source is the National Accounts of Pakistan, 2007, prepared by the Federal Bureau of Statistics. The other data sources include Economic Surveys by The Finance Division, 2006-07 and Annual Reports, 2006 \& 2007 by the State Bank of Pakistan, the Central Bank.

\subsection{Descriptive Statistics}

This study is based on the descriptive statistics that shows the basic characteristics of the variables used in the analysis. An easy and quick way to know the relationship between stock prices and macro variables is to find the correlations between them.

\subsection{Correlation Coefficient}

As a preliminary analysis, the correlation coefficients are calculated. In addition to the full sample, the correlations are also calculated for two sub-samples consisting of periods from December 1980 to March 1991 and from April 1991 to June 2007. The division of the sample is done to examine the effects of various economic reforms on the relationship. (Fazal Husain, 2006)

\subsection{Augmented Dickey Fuller (ADF)}

The formal investigation starts with examining the stochastic properties of the variables used in the analysis. Hence, the Unit Root Test is performed on the variables to test the stationary variables. In this context, the widely used Augmented Dickey Fuller (ADF) is used.

\subsection{Co-integration Analysis}

The relationship, however, is formally investigated through Co-integration and error correction analysis. In this context, first performing Unit Root Test tests the stationary variables. For this purpose the study used the Augmented Dickey Fuller (ADF) Test. Then, the researcher examined the existence of long-run relations between stock prices and macro variables with the help of Co-integration analysis suggested by Engle and Granger (1987).

\subsection{Error Correlation Model (ECM):}

Finally, the causal relations were examined through the Error Correction Model (ECM). The ECM is an extension of the Granger causality test where an error correction term is introduced into the test, that is:

$$
\begin{aligned}
& \Delta Y_{t}=\alpha_{1}+\rho_{1} e_{t-1}+\sum_{i=1}^{p} \beta_{i} \Delta Y_{t-i}+\sum_{j=1}^{q} \delta_{j} \Delta X_{t-j} \\
& \Delta X_{t}=\alpha_{2}+\rho_{2} e_{t-1}+\sum_{i=1}^{p} \beta_{i} \Delta Y_{t-i}+\sum_{j=1}^{q} \delta_{j} \Delta X_{t-j}
\end{aligned}
$$


Where, $e_{t-1}$ is an error correction term, representing the long-run relationship. A negative and significant coefficient indicates the presence of long-run causal relationship. If both coefficients are significant, this will suggest the bi-directional causality. If, e.g., only $\mathrm{p}_{1}$ is significant, this will suggest a unidirectional causality from $X$ to $Y$, implying that $X$ drives $Y$ toward long-run equilibrium but not the other way around.

On the other hand, the lagged terms of $\Delta Y_{\mathrm{t}}$ and $\Delta X_{\mathrm{t}}$, found as explanatory variables, indicate short-run cause-and-effect relationship between the two series. Thus, if the lagged coefficients of $\Delta X_{\mathrm{t}}$ appear to be significant in the regression of $\Delta Y t$, this means that $X$ causes $Y$.

\subsection{Dummy Variable:}

As mentioned above, the Pakistan economy has been brought under various economic reforms in the 1990s (Fazal Husain, 2006). The most significant measure is the opening of the Pakistani equity market to international investors in early 1991. To take care of these reforms, a dummy variable is used for the period from April 1991 to June 2007.

\section{Data Analysis}

The empirical results and interpretations of the study are discussed as below:

\subsection{Descriptive Statistics for Growth in Stock Prices and Macro Variables}

The undertaken study presenting the descriptive statistics of the variables used in the analysis is shown in the following three tables:

TABLE - 1 (a)

Descriptive Statistics for Growth in Stock Prices and Macro Variables:

Total Sample: Dec. 1980 - June 2007

\begin{tabular}{|c|c|c|c|}
\hline \multicolumn{4}{|c|}{ Descriptive Statistics } \\
\hline & \multicolumn{3}{|c|}{ (Dec. 1980 - June 2007) } \\
\hline & $\mathrm{D}(\mathrm{SP})$ & $\mathrm{D}(\mathrm{GDP})$ & $\mathrm{D}(\mathrm{INV})$ \\
\hline Mean & 0.0286 & 0.0099 & 0.0107 \\
\hline Std. Dev. & 0.1184 & 0.1452 & 0.1221 \\
\hline Skew-ness & 0.4776 & 0.5598 & -0.7757 \\
\hline Kurtosis & 3.8994 & 2.0286 & 3.5678 \\
\hline Observations & 106 & 106 & 106 \\
\hline
\end{tabular}

TABLE - 1 (b)

Descriptive Statistics for Growth in Stock Prices and Macro Variables: Sample I: Pre Liberalization: Dec. 1980 - March 1991

\begin{tabular}{|c|c|c|c|}
\hline \multicolumn{4}{|c|}{ Descriptive Statistics } \\
\hline & \multicolumn{3}{|c|}{ (Dec. 1980 - March 1991) } \\
\hline & $\mathrm{D}(\mathrm{SP})$ & $\mathrm{D}(\mathrm{GDP})$ & $\mathrm{D}(\mathrm{INV})$ \\
\hline Mean & 0.0300 & 0.0126 & 0.0189 \\
\hline Std. Dev. & 0.0451 & 0.1618 & 0.1108 \\
\hline
\end{tabular}




\begin{tabular}{|c|c|c|c|}
\hline Skew-ness & 0.3597 & 0.4698 & -0.7423 \\
\hline Kurtosis & 3.8060 & 1.9229 & 3.3115 \\
\hline Observations & 41 & 41 & 41 \\
\hline
\end{tabular}

TABLE - 1 (c)

Descriptive Statistics for Growth in Stock Prices and Macro Variables: Sample II: Post Liberalization: April 1991 - June 2007

\begin{tabular}{|c|c|c|c|}
\hline \multicolumn{4}{|c|}{ Descriptive Statistics } \\
\hline & \multicolumn{3}{|c|}{ (April 1991 - June 2007) } \\
\hline & $\mathrm{D}(\mathrm{SP})$ & $\mathrm{D}(\mathrm{GDP})$ & $\mathrm{D}(\mathrm{INV})$ \\
\hline Mean & 0.0277 & 0.0081 & 0.0056 \\
\hline Std. Dev. & 0.1475 & 0.1349 & 0.1292 \\
\hline Skew-ness & 0.4177 & 0.6270 & -0.7520 \\
\hline Kurtosis & 2.6687 & 2.0122 & 3.5110 \\
\hline Observations & 65 & 65 & 65 \\
\hline
\end{tabular}

The summary of the descriptive analysis of the data is divided into three periods (Table 1a, 1b, 1c) as the total sample comprises of data ranging from December 1980 to June 2007, whereas, the whole set of data again is divided into two periods. The first category is called "Pre liberalization" period which comprises of data from December 1980 to March 1991 and the second category "Post liberalization” period is from April 1991 to June 2007.

The tables 1a, $1 \mathrm{~b}$ and $1 \mathrm{c}$ indicate that the stock market in Pakistan provides an average quarterly return just under $2.86 \%$. On the other hand, the average annual growth in real variables is just lower than 1\% in GDP, whereas, slightly over than $1 \%$ in investments. However, the volatility in the stock price index, measured by the standard deviation, is much higher relative to the real variables. The real variables seem to be much stable during the sample period.

A comparison of the descriptive statistics between the two sub-periods indicates decline in the average growth in real variables. Hence, real GDP fell from $1.26 \%$ to $0.81 \%$ whereas real investment decreased from $1.89 \%$ to $0.56 \%$. However, the decline is significant both in GDP and investment. Though the magnitude of the average growth in stock price index increased in the second period it is not significantly different from that of the first period. On the other hand, the stock price is the only variable that experienced significant increase in volatility in the second period. In the case of real variables the variances are not significantly different between the two sub-periods. Therefore, it is concluded that the average quarterly return for the full sample is $2.86 \%$, whereas, the average return fell from $3.00 \%$ to $2.77 \%$ in sample II but volatility increased more than three times from 4.50 to 14.75 .

\subsection{The Correlation Coefficient of Stock Prices and Macro Variables}

The correlation coefficient of stock prices changes with changes in real investment and real GDP are presented as follows: 
TABLE - 2 (a)

Correlation Coefficients between Stock Prices and Macro Variables: Total Sample: Dec. 1980 - June 2007

\begin{tabular}{|c|c|c|c|}
\hline \multicolumn{4}{|c|}{ Correlations } \\
\hline & \multicolumn{3}{|c|}{ (Dec. 1980 - June 2007) } \\
\hline & $\mathrm{D}(\mathrm{SP})$ & $\mathrm{D}(\mathrm{GDP})$ & $\mathrm{D}(\mathrm{INV})$ \\
\hline $\mathrm{D}(\mathrm{SP})$ & 1.0000 & 0.0287 & 0.0427 \\
\hline $\mathrm{D}(\mathrm{GDP})$ & 0.0287 & 1.0000 & 0.6702 \\
\hline $\mathrm{D}(\mathrm{INV})$ & 0.0427 & 0.6702 & 1.0000 \\
\hline
\end{tabular}

TABLE - 2 (b)

Correlation Coefficient between Stock Prices and Macro Variables: Sample I: Pre Liberalization: Dec. 1980 - March 1991

\begin{tabular}{|c|c|c|c|}
\hline \multicolumn{4}{|c|}{ Correlations } \\
\hline & \multicolumn{3}{|c|}{ (Dec. 1980 - March 1991) } \\
\hline & $\mathrm{D}(\mathrm{SP})$ & $\mathrm{D}(\mathrm{GDP})$ & $\mathrm{D}(\mathrm{INV})$ \\
\hline $\mathrm{D}(\mathrm{SP})$ & 1.0000 & -0.2595 & 0.0155 \\
\hline $\mathrm{D}(\mathrm{GDP})$ & -0.2595 & 1.0000 & 0.6594 \\
\hline $\mathrm{D}(\mathrm{INV})$ & 0.0155 & 0.6594 & 1.0000 \\
\hline
\end{tabular}

TABLE - 2 (c)

Correlation Coefficient between Stock Prices and Macro Variables: Sample II: Post Liberalization: April 1991 - June 2007

\begin{tabular}{|c|c|c|c|}
\hline \multicolumn{3}{|c|}{ Correlations } \\
\hline & \multicolumn{3}{|c|}{ (April 1991 - June 2007) } \\
\hline & $\mathrm{D}(\mathrm{SP})$ & $\mathrm{D}(\mathrm{GDP})$ & $\mathrm{D}(\mathrm{INV})$ \\
\hline $\mathrm{D}(\mathrm{SP})$ & 1.0000 & 0.1000 & 0.0500 \\
\hline $\mathrm{D}(\mathrm{GDP})$ & 0.1000 & 1.0000 & 0.6924 \\
\hline $\mathrm{D}(\mathrm{INV})$ & 0.0500 & 0.6924 & 1.0000 \\
\hline
\end{tabular}

It shows in Table 2-a, that the correlations are very low and not significantfor both GDP and investments. Similarly, in table 2-b, the first sub-sample, consisting of pre-reform period, the correlations are again very low. However, the post reform period shows a significant increase in correlation coefficients in table 2-c, indicating the beginning of association of stock prices with real variables following liberalization measures. In particular, the correlation between stock prices and GDP is high as compared to INV. Correlation with GDP increased significantly in the post liberalization period from -0.26 to 0.1 .

\subsection{Efficiency of the Stock Market in Post-Liberalization Period}

The efficiency of the stock market in post liberalization period is investigated through QStatistics. 
The Q-Statistics imply that the market is efficient during the post liberalization period because the probabilities are more than 0.05 .

\subsection{Causal Relations between Stock Prices and the Variables}

The formal investigation of causal relations between stock prices and the variables representing the real sector is done with the help of Co-integration and Error Correction Model framework. At the first step, the ADF unit root test is applied to all the variables to examine the stochastic properties of these variables. The test is applied to both the original series and to the first differences of the series. Moreover, both the models with and without trend are tested. The results are reported in Table 3, which indicate that the variables are integrated of order one (I).

TABLE - 3

Unit Root Test (ADF) for Variables

\begin{tabular}{|l|l|l|l|l|}
\hline & \multicolumn{3}{|c|}{ Unit Roots } \\
\hline & \multicolumn{2}{|c|}{ Levels } & \multicolumn{2}{c|}{ First Diff. } \\
\hline & Without & With & Without & With \\
\hline & Trend & Trend & Trend & Trend \\
\hline SP & -1.023 & -1.973 & $-.755^{* * *}$ & $-.723^{* * *}$ \\
\hline GDP & -2.533 & 0.090 & $-.374^{* * *}$ & $-.584^{* * *}$ \\
\hline INV & -2.058 & -2.558 & $-.345^{* * *}$ & $-.356^{* * *}$ \\
\hline
\end{tabular}

The unit root test (ADF) shows that variables are not stationary at levels but become stationary at first difference because the values are significant, implying that they are integrated of order one.

\subsection{The Long-run Relations of Stock Prices with the Real Variable}

At the second step, the co-integrating regressions suggested by Engle-Granger are estimated to examine the long run relations of stock prices with the real variables. The results are shown in Table 4(a) \& 4(b).

TABLE - 4 (a)

Co-Integrating Regressions: Sample I: Pre Liberalization Period

\begin{tabular}{|l|c|c|c|}
\hline \multirow{2}{*}{ Regressions } & \multicolumn{3}{|c|}{ Co-Integration } \\
\cline { 2 - 4 } & Const. & Co-eff. & ADF \\
\hline GDP on SP & 9.606 & 0.355 & -1.81 \\
\hline INV on SP & 10.315 & 0.250 & $-2.52^{* *}$ \\
\hline
\end{tabular}

The ADF is significant and indicating the existence of a long run relation between stock prices (SP) and investment (INV) but not with GDP. Therefore, it is concluded that in prereform period there is a long run relationship existing between stock prices and investment but there is no evidence of long relationship between stock prices and the GDP because of weak $\mathrm{ADF}$ value. 
TABLE - 4 (b)

Co-Integrating Regressions: Sample II: Post Liberalization Period

\begin{tabular}{|c|c|c|c|}
\hline Regressions & \multicolumn{3}{|c|}{ Co-Integration } \\
\hline & Const. & Co-eff. & ADF \\
\hline GDP on SP & 11.12 & 0.132 & $-2.339^{* *}$ \\
\hline INV on SP & 11.305 & 0.104 & $-4.425^{* * *}$ \\
\hline
\end{tabular}

In post liberalization period the ADF is less significant in the case of GDP, whereas, more significant in case of INV, however in both cases this indicates a long run relationship of Stock prices (SP) with GDP and investment (INV).

\subsection{The Direction of Causality between Two Variables}

Finally, the causal relations were examined through the Error Correction Model (ECM). The ECM is an extension of the Granger Causality test where an error correction term is introduced into the test, that is:

$$
\begin{aligned}
& \Delta Y_{t}=\alpha_{1}+\rho_{1} e_{t-1}+\sum_{i=1}^{p} \beta_{i} \Delta Y_{t-i}+\sum_{j=1}^{q} \delta_{j} \Delta X_{t-j} \\
& \Delta X_{t}=\alpha_{2}+\rho_{2} e_{t-1}+\sum_{i=1}^{p} \beta_{i} \Delta Y_{t-i}+\sum_{j=1}^{q} \delta_{j} \Delta X_{t-j}
\end{aligned}
$$

[This model has already been explained in chapter three, research methodology].

The Granger Causality indicates no causal relationship between stock prices and GDP. Moreover, it indicates no causal relationship in both long and short run. So, it is concluded that stock prices do not have any causal relationship on Gross Domestic Products (GDP) either in long run or short run in full sample period i.e. from December 1980 to June 2007.

The ECM verifies the long run relation between SP and INV and indicates a bidirectional causality. The INV affects the SP only in the long run but SP affects INV not only in the long run, but also in the short run for up to three quarters. So, it is concluded that there is a relationship between stock prices and the investments and further concluded there is a bidirectional causality between investments and the stock prices.

\section{Post Liberalization Period}

The Error Correction Models are also estimated to examine the direction of causality between two variables for post liberalization period. Residuals clearly explain the causality \& effect of the variables.

The Error correction Model (ECM) does not verify the long run relation between stock prices (SP) and GDP. It also indicates no causal relationship both in the long run and short run in post liberalization period.

The Granger analysis indicates no causal relationship between Stock prices and GDP. Therefore, it is concluded that there is no causal relationship between stock prices and the GDP in post liberalization period. 
The residuals analysis verifies the long run relation between Stock prices and Investments and indicates a bi-directional causality where investments affects the Stock prices only in the long run but Stock prices affects investments not only in the long run but also in the short run for up to three quarters as well.

Hence the researcher can conclude that the stock market in Pakistan is not that developed to influence the real sector and therefore cannot be considered as the leading indicator of the economy. However, the results may be affected by the shifts in the data due to the liberalization of the stock market as well as the economy in the early 1990s.

\subsection{Shifts in Stock Prices and Real Variables}

To take care of the shifts in variables representing the stock market as well as the real sector due to the liberalization measures the researcher introduces a dummy variable in the analysis that takes the value of one from 1991/92 onwards. Once again the study start by estimating the cointegrating regressions reported in Table 5.

TABLE - 5

Co-integrating Regressions Including Shift in Variables

\begin{tabular}{|l|l|l|l|l|}
\hline \multicolumn{1}{|c|}{ Regression } & Constant & Dummy & Coefficients & ADF \\
\hline GDP on & $\begin{array}{l}11.101^{* *} \\
\text { SP }\end{array}$ & - & $\begin{array}{l}0.600^{* *} \\
*\end{array}$ & $-2.132^{*}$ \\
\hline Inv on SP & $\begin{array}{l}* 1.213^{* *} \\
*\end{array}$ & - & $\begin{array}{l}0.127 \\
*\end{array}$ & - \\
\hline
\end{tabular}

The table- 5 shows that the values of dummy variable are very low as compared to the other variables and dummy variable is not significant anywhere implying that the relations of stock prices with the variables representing real sector are not affected by the liberalization measures. Hence, the researcher may not expect any significant change in his conclusion derived earlier. It can be further concluded that despite significant developments in the stock market like market capitalization, high trading volume or high market index etc., the stock market in Pakistan is still not in a position to influence the real sector.

\section{Summary, Conclusion and Recommendation}

The summary, conclusion and the recommendations of the study are on the basis of the empirical results that are given as follows:

\subsection{Summary and Conclusions:}

- $\quad$ The summary of the descriptive analysis of the data is divided into three periods as the total sample comprising data from December 1980 to June 2007. The whole set of data again is divided into two periods, Pre liberalization period (December 1980 to March 1991), The Post liberalization period (April 1991 to June 2007).

- $\quad$ The stock market in Pakistan provides an average quarterly return of $2.86 \%$.The average annual growth in real variables is just lower than $1 \%$ in GDP and slightly over than $1 \%$ in investments.

- A comparison of the descriptive statistics between the two sub-periods indicates decline in the average growth in real variables. Real GDP fell from $1.26 \%$ to $0.81 \%$ and real investment decreased from $1.89 \%$ to $0.56 \%$. The decline is significant both in GDP and 
investment. Though the magnitude of the average growth in stock price index increased in the second period it is not significantly different from that of the first period.

- $\quad$ The stock price is the only variable that experienced significant increase in volatility in the second period. In the case of real variables the variances are not significantly different between the two sub-periods.

- $\quad$ It is concluded that the average quarterly return for the full sample is $2.86 \%$, whereas, the average return fell from $3.00 \%$ to $2.77 \%$ in sample II but volatility increased more than three times from 4.50 to 14.75 .

- $\quad$ The descriptive statistics indicate a much higher expansion in stock prices relative to real variables. However, the stock prices also experienced high volatility during the sample period whereas the real variables seem to be stable.

- $\quad$ The correlations are very low and not significant in the cases of GDP and investment in full sample period. The first sub-sample, consisting of pre-reform period, the correlations is again very low and not significant.

- $\quad$ The post reform period shows a significant increase in correlation coefficients. In particular, the correlation between stock prices and GDP is very high. Correlation with GDP increased significantly in the post liberalization period from -0.26 to 0.1 .

- The correlation analysis shows low correlations between stock prices and macro variables. However, there is evidence of significant increase in these correlations in the period subject to reforms, suggesting that these reforms resulted in significant improvement in the behavior of stock market and its linkages to the economy.

- $\quad$ The Q-Statistics imply that the market is efficient during the post liberalization period because the values of probabilities are very low and less than 0.05 .

- $\quad$ Augmented Dickey Fuller (ADF) shows that variables are not stationary at levels but become stationary at first difference, implying that they are integrated of order one.

- $\quad$ The Augmented Dickey Fuller (ADF) is significant and indicates the existence of a long run relation between stock prices and investment but not with GDP. In post liberalization period the Augmented Dickey Fuller (ADF) is significant, indicating a long run relationship of Stock prices with GDP and investment as well.

- $\quad$ The relationship, however, is formally investigated through Co-integration and error correction analysis.Then, the researcher examined the existence of long-run relations between stock prices and macro variables with the help of Co-integration analysis suggested by Engle and Granger (1987).

- The Granger Causality indicates no causal relationship between stock prices and GDP.Moreover, it indicates no causal relationship both in the long run and the short run as well. Therefore, the analysis does not verify the evidence of improvement in the linkages of stock market to the economy, which is indicated by the correlation analysis.

- $\quad$ Finally, the causal relations were examined through the Error Correction Model (ECM). The ECM is an extension of the Granger Causality Test. The Error Correction Model (ECM) verifies the long run relation between Stock prices and investment and indicates a bi-directional causality where investment affects the stock prices only in the long run but stock prices affects investment not only in the long run but also in the short run for up to three quarters.

- $\quad$ Moreover, the Error correction Model (ECM) does not verify the long run relation between stock prices and GDP. It indicates no causal relationship both in the long run and short run. 
- $\quad$ The results may be affected by the shifts in the data due to the liberalization of the stock market as well as the economy in the early 1990s. The dummy variable is not significant anywhere implying that the relations of stock prices with the variables representing real sector are not affected by the liberalization measures. Hence, the researcher may not expect any significant change in his conclusion derived above. Hence it can be concluded that despite significant developments the stock market in Pakistan is still not in a position to influence the real sector.

The above findings of the study suggested that the stock market in Pakistan is still quiteunder developed to play its due role in influencing the real sector of the economy. However it can be implied, that the government can use the real sector to influence the stock market. An important implication of the findings is that the stock market in Pakistan cannot be characterized as the leading indicator of the economic activity. The study clearly indicates that it lags economic activity. It seems that the phenomenal growth in stock market variables like market capitalization, trading volume, the market index etc. do not seem to influence the economy of Pakistan.

\subsection{Recommendations:}

The study clearly indicates that it lags economic activity i.e. the Stock market does not lead the economy rather the economy leads the Stock market. Therefore, individuals, institutions and government should be aware of the resulting speculative bubbles. In the absence of other strong economic indicators, all the stake holders should be cautious when stock prices shoot up.

It is further recommended that the government should take appropriate steps in order to rectify the market development and offer better financial infrastructure for operation of stock markets. These include strengthening of regulatory provisions and better enforcement, improvements in information systems and mechanisms for payments, more neutral application of fiscal policy to all types of financial instruments, higher standards of disclosure of financial information by companies, and greater scope for financial innovation within a flexible regulatory framework. Researcher expects that progress in these areas will substantially enhance the role of stock markets in the economic development of Pakistan in the coming years.

This study was done to examine the causal relationship between stock prices and the variables representing real GDP, and real investment, in Pakistan.It is suggested that further research can be done on the causal relationship between stock prices and the rest of the macro economic variables like inflation, poverty, consumption etc.

In this study the time period considered is from December 1980 to June 2007.Further

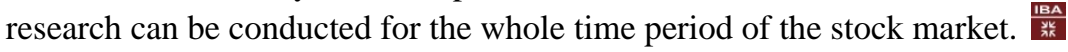

\section{References}

Agtmael, A., and V. Errunza."Foreign Portfolio Investment in Emerging Securities Market.”Columbia Journal of World Business (1982): 35-63.

Ahmed, E., and J.B. Rosser Jr. "Non-linear Speculative Bubbles in the Pakistani Stock Market.”Pakistan Development Review 34 (1995): 25-41.

Ahmed, M. F., "Stock Market, Macroeconomic Variables, and Casualty: The Bangladesh Case," Savings and Development, No. 2, 1999.

Ahmed, Rashid. "Betting on Bhutto".Far Eastern Economic Review (February 17, 1994) 46-47. 
Ando, A. and Modigliani, F., “The Life Cycle Hypothesis of Saving: Aggregate Implication and Tests,” American Economic Review, Vol. 53, No. 1, 1963.

Khan A. H., “The Experience of Trade Liberalization in Pakistan”, Pakistan Development Review 37, No. 4 (Winter 1998), 661.

Atje, Raymond and Jovanovic, Boyan. "Stock Markets and Development”, European Economic Review, April 1993, 37 (2/3), pp. 632-640.

Bagehot, Walter. Lombard Street. Homewood, IL: Richard D. Irwin, 1873 (1962 Edition).

Barro, Robert J. “Convergence”, Journal of Political Economy, 1992, 100, pp. 223-51.

Baumol, W. “Stock Market and Economic Efficiency”, Fordham University Press, New York, 1965.

Bekaert, Geert and Harvey Campbell R. "Time-Varying World Market Integration", Journal of Finance, June, 1995, 50(2), pp. 403-444.

Bencivenga, Valerie R. and Smith, Bruce D. "Financial Intermediation and Endogenous Growth”, Review of Economics Studies, April 1991, 58(2), pp. 195-209.

Bhide\& Amar. "The Hidden Costs of Stock Market Liquidity", Journal of Financial Economics, 1993, 34, pp. 31-51.

Bosworth, B., “The Stock Market and the Economy”, Brookings Papers on Economic Activity, vol. 2, 1975.

Bruno, Michael and Easterly, William. "Inflation Crises and Long-Run Growth", July 1995, Washington, DC: World Bank, Mimeo.

Chan, K., B. Gup, and M. Pan. “An Empirical Analysis of Stock Prices in Major Asian Markets and the United States".The Financial Review 27 (1992) 289-307.

Chandavarkar, Anand. “Of Finance and Development: Neglected and Unsettled Questions,” World Development, January 1992, 20(1), pp. 133-142.

Cohen, Patrick D., 1966. "Presyllables and Duplication in Jeh".Mon-Khmer Studies 2: 31-40. Previously Published: Van-hóaNguyêt-san 14: 887-896.

Conard, K. and D. Juttner."Recent Behavior of Stock Market Prices in Germany and the Random Walk Hypothesis".Kyklos 26 (1973): 576-599.

Corhay, A., and Tourani Rad. "Statistical Properties of Daily Returns: Evidence of European Stock Markets”. Journal of Business Finance and Accounting 21(2) (1994): 271-282,

De Gregorio, Jose and Giudotti, Pablo E. “Financial Development and Economic Growth”, World Development, 1995, 23(3) pp. 433-448.

Demirguc-Kunt, Asli and Levine, Ross. "Stock Market Development and Financial Intermediaries: Stylized Facts”, World Bank Economic Review, 1996, this issue.

Devereux Michael B., and Smith, Gregor, W. “International Risk Sharing and Economic Growth”, International Economic Review, August 1994, 35(4), pp. 535-50. 
Diamond, Douglas W. and Verrecchia, Robert E. "Optimal Managerial Contracts and Equilibrium Security Prices", Journal of Finance, May 1982, 37, pp. 275287.

Divecha, A., J. Drach, and D. D. Stefek."Emerging Markets: A Quantitative Perspective".Journal of Portfolio Management (1993): 41-50.

Economist Intelligence Unit, Pakistan Country Report, First Quarter (February) 1999.

Engle, R. and C. Granger."Cointegration and Error Correction: Representation, Estimation and Testing", Econometrica, 55, 1987.

Errunza, V. "Efficiency and the Programs to Develop Capital Markets: The Brazilian Experience”. Journal of Banking and Finance 3 (1979): 355-382.

Errunza, V. "Emerging Markets: A New Opportunity for Improving Global Portfolio Performance”. Financial Analyst Journal (1983): 51-58.

Fama, Eugene F., 1998. “Market Efficiency Long-term Returns, and Behavioral Finance.”Journal of financial Economics 49 (1998) 283-306.

Fisher, Stanley “The Role of Macroeconomic Factors in Growth." Journal of Monetary Economics, December 1993, 32 (3): 485-51 1.

Gelb, Alan H. "Financial Policies, Growth, and Efficiency”, Washington, DC, World Bank PPR Working Paper WPS 202, June 1989.

Gill, David and Peter Tropper, "ESMs in Developing Countries", Finance and Development IMF/World Bank Publication (International), 25:28-31, December 1988.

Goldsmith, Raymond, W. Financial Structure and Development. New Haven, CT: Yale University Press, 1969.

Granger, C.W.J., and Merganser, “The Predictability of Stock Market Prices”, Lexington, Mass, Heath Lexington Books, Heath \& Co., 1970.

Grossman, S.And Stiglitz, J. “On the Impossibility of Informational Efficient Markets,” American Economic Review, 1980, 70, Pp.393-408.

Hartmann, M., and DaraDhambata “Emerging Stock Markets: Investment Strategy of Future.” Columbia Journal of World Business (1993): 82-104.

Harvey, Campbell R. "Predictable Risk and Returns in Emerging Markets," Review of Financial Studies, 1995, Forthcoming.

Husain F. and T. Mahmood, “The Stock Market and the Economy in Pakistan," Pakistan Development Review, 2001.

Holmstrom, Bengt, and Tirole, Jean."Market Liquidity and Performance Monitoring,” Journal of Political Economy, August 1993, 101(4), Pp. 678-709.

Husain, F. "Stock Price Behavior in an Emerging Market: A Case Study of Pakistan.” Ph.D. Dissertation, Catholic University of America, 1996.

Husain I., “Strategy for External Debt Management: 1999-2004,” http: //www. sbp.org.pk/about/speech/2002/6-mar-02.pdf,2. 
J. EitemanWilford, A. Dice K. Eiteman, “The Stock Market: N.Y., McGraw-Hill, 1966.

Jesen, M. 1978. Some Anomalous Evidence Regarding Market Efficiency, Journal of Financial Economics, 6, 95-102.

John Hicks, Measurement of Capital - In Practice: 1969, Bulletin of ISI.

K.F. Kyle, “An Econometric Model of Internal Migration and Development: Extensions and Tests,” Regional Science and Urban Economics, 14 (March 1984)77-87.

Khan, M.The Securities Market in Pakistan. Pakistan: Royal Book Company, 1993.

Khilji, N. "Nonlinear Dynamics and Chaos: Application to Financial Markets in Pakistan." Pakistan Development Review 33 (1994): 593-604.

King, Robert G. and Levine Rose."Finance, Entrepreneurships, and Growth: Theory and Evidence”, Journal of Monetary Economics, December 1993, 32 (3), Pp.42.

Korajczyk, Robert A. “A Measure of Stock Market Integration,” World Bank Economic Review, 1996, This Issue.

Larosence Steve, "International Accounting: London, International Thomson Business Series, 1999.

Levine, Ross and Zervos, Sara. "What we have learned about policy and growth from Cross Regressions”, American Economic Review, May, 1993, Pp. 426-430.

Lore James, Dodd Peter, Kempton Hampton Merry, “The Stock Market: Theory and Evidence”, Illinois, Richard D. Irwin, Ins. 1985.

Lucas, Robert E. “On the Mechanics of Economic Development”, Journal of Monetary Economics, July 1988, 22(1), Pp.3-42.

Mankiw, N. Gregory; Fomer, David; and Weil David. Contrition to the Empirics of Economic Growth”, Quarterly Journal of Economics, 1992, 107, Pp. 407-437.

Mc. Milan. G. Lawrence, “Options as a Strategic Investment”, N.Y., New York Institute of Finance, 1986.

Mckinnon, Ronald I. Money and Capital in Economic Development.Washington, DC; Brooking Institution, 1973.

Medewtiz, J., F. Abdullah, and K. Olson."Integration of World Equity Markets; the Recent Evidence”.The International Journal of Finance 4 (1991): 34-46.

Meier, Gerald M. and Seers, Dudley.Pioneers in Development.New York; Oxford University Press, 1984.

Michael Melvin, “International Money and Finance: N.Y., Harper Collins, 1995.

Mills, Terence. The Econometric Modeling of Financial Time Series, England: Camp Bridge University Press, 1993.

Ministry of Commerce, "Text of the Trade Policy of Pakistan" (Islamabad: Government of Pakistan, 2001). 
Morck, Randal; Shleifer, Andrei, and Vishny, Robert W. “The Stock Market and Investment; Is the Market a Sideshow? Brookings Papers on Economic Activity, 1990a, 2, Pp. 157-215.

Obstfeld, Maurice. 'Risk-Taking, Global Diversification, and Growth", American Economic Review, December 1994, 84(5), Pp. 1310-1329.

Pagan, Adrian. "Econometric Issues in the Analysis of Regression with Generated Regresses”, International Economic Review, February 1984, 25, (1), 221-247.

Pakistan, Government of 50 Years of Pakistan in Statistics, Federal Bureau of Statistics, 1998.

Pakistan, Government, Economic Survey, Ministry of Finance, (Various Issues)

Robinson, Foan. “The Generalization of the General Theory”, In the Rate of Interest and Other Essays, 1952, London: Macmillan.

Rousseau, Peter L. \& Sylla, Richard, 2005. "Emerging Financial Markets and Early US Growth” Explorations in Economic History, Elsevier, Vol, 42(1), Pages 1- 26, January.

Scharfstein, David. “The Disciplinary Role of Takeovers” Review of Economic Studies, April 1988, 55, Pp.185-99.

Shleifer, Andrei and Vishny, Robert W. "Large Shareholders and Corporate Control, Journals of Political Economy, 1986, 461-488.

State Bank of Pakistan.Equity Yields on Ordinary Shares, Karachi, SBP, 2001.

State Bank of Pakistan.Index Numbers of Stock Exchange Securities, Pakistan, various years.

Stiglitz, Joseph E. “The Role of the State in Financial Markets”, Proceedings of the Annual Bank Conference on Development Economics.1993, Pp.19-52.

Uppal, J. “The Internationalization of the Pakistani Stock Market: An Empirical Investigation”. Pakistan Development Review (1993): 605-618.

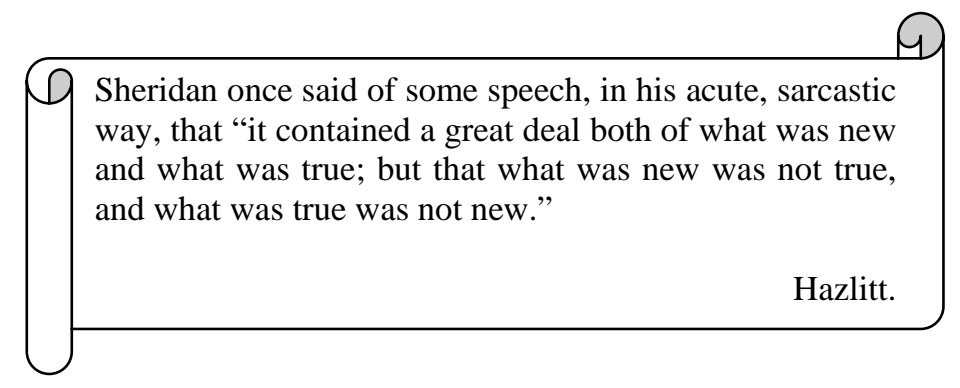

